\title{
Gas Exchange in an Air-Breathing Fish, the Snakehead Channa argus, in Normoxic and Hypoxic Water and in Air
}

\author{
Yasuo ItaZawa and Atsushi Ishimatsu*
}

(Received February 19, 1981)

\begin{abstract}
Gas exchange in an air-breathing fish, the snakehead Channa argus, was measured when the fish breathed bimodally in normoxic $\left(P_{\mathrm{w}, \mathrm{o}_{2}} \geqq 130 \mathrm{mmHg}\right)$ and hypoxic $\left(\mathrm{P}_{\mathrm{w}, \mathrm{o}_{2}} \leqq 40 \mathrm{mmHg}\right)$ water and when the fish was exposed to air at $25^{\circ} \mathrm{C}$. During bimodal breathing, total $\dot{\mathrm{M}}_{\mathrm{O}_{2}}$ and total $\dot{\mathrm{M}}_{\mathrm{CO}_{2}}$ remained constant regardless of change in $\mathrm{P}_{\mathrm{W}, \mathrm{O}_{2}}$. Of the total $\dot{\mathrm{M}}_{\mathrm{O}_{2}}$ about $60 \%$ and $85 \%$ were satisfied by air breathing in normoxic and hypoxic water, respectively. Contribution of air breathing to total $\dot{\mathrm{M}}_{\mathrm{CO}_{2}}$ was small (about $15 \%$ of the total) and was unaffected by $\mathrm{P}_{\text {Wo, },}$. Thus, water breathing contributed mainly to $\mathrm{CO}_{2}$ release and less to $\mathrm{O}_{2}$ uptake. When the fish was exposed to air, $\dot{\mathrm{M}}_{\mathrm{O}_{2}}$ and $\dot{\mathrm{M}}_{\mathrm{CO}_{2}}$ did not significantly differ from total $\dot{\mathrm{M}}_{\mathrm{O}_{2}}$ and $\dot{\mathrm{M}}_{\mathrm{OO}_{2}}$ during bimodal breathing. The gas exchange ratio was 0.75 in this condition. Frequency of gill ventilation markedly increased after the fish was returned to water, and this may imply that $\mathrm{CO}_{2}$ accumulated to some extent during exposure to air.
\end{abstract}

Many animals are known to have two different respiratory organs operating concurrently. The three living genera of lungfishes are well known examples of such animals. Besides lungfishes, however, many air-breathing teleosts come under this category. These air-breathing fishes have developed diverse structures to breathe atmospheric air (JOHANSEN ${ }^{1)}$, MUNSHI ${ }^{2)}$ ).

A snakehead Channa argus is an air-breathing fish which is widely distributed in freshwater marshes and creeks in East Asia. In Japan, the fish was introduced from Korea and now inhabits almost all areas of the country. This species, like others of Channa, has a pair of specialized air-breathing organs associated with the pharyngeal and opercular cavities. The basic structure of the organ is similar in all species of Channa, and is composed of a suprabranchial chamber into which two processes project (FUKUDA ${ }^{8}$, MUNSHI ${ }^{4)}$ ). Rich vascularization was observed in the airbreathing organ (IsHIMATsu et al. ${ }^{5}$ ).

It is known that the snakehead cannot survive long when it is submerged underwater without access to air and also when removed from water (UCHIDA and FUנIMOTO ${ }^{8)}$ ). These facts suggest that both aerial and aquatic gas exchanges are essential to the fish. The present study seeks to determine gas exchange when the snakehead breathes bimodally in normoxic and hypoxic water and when the fish is exposed to air.

\section{Material and Methods}

Sixteen specimens of the snakehead weighing between 400 and $800 \mathrm{~g}$ were collected on hook and line in Fukuoka Prefecture. The fish were maintained individually in tanks in a room of a constant temperature of $25 \pm 1^{\circ} \mathrm{C}$ for at least three weeks before experimentation. All experiments were carried out at this temperature. The fish were fed on live frogs or fish every other day, and only healthy fish were used for experiment. Much care was taken not to disturb the fish before and during the experiment.

Gas exchange with air and water during bimodal breathing was measured in normoxic $\left(\mathbf{P}_{\mathrm{w}, \mathrm{o}_{2}} \geqq\right.$ $130 \mathrm{mmHg})$ and hypoxic $\left(\mathrm{P}_{\mathrm{w}, \mathrm{o}_{2}} \leqq 40 \mathrm{mmHg}\right)$ water using an experimental arrangement slightly modified from that described by EMIIIO and SHELTON?? (Fig. 1a). A plexiglass box which contained $48 l$ of water and $0.2 l$ of air was used as a respiration chamber. A fish starved for $24 \mathrm{~h}$ was transferred to the chamber and left overnight or more to acclimate to the condition. During the acclimation period well aerated water was gently circulated through the chamber, and fresh air was continuously introduced into the gas space (G). In hypoxia experiments nitrogen was bubbled through the equilibration column (EC) for several hours before experiments.

At the beginning of an experiment, both inlet

* Department of Fisheries, Faculty of Agriculture, Kyushu University, 46-4, Hakozaki, Higashi-ku, Fukuoka 812 (板沢靖男・石松 嵉: 九州大学串学部水産学科). 


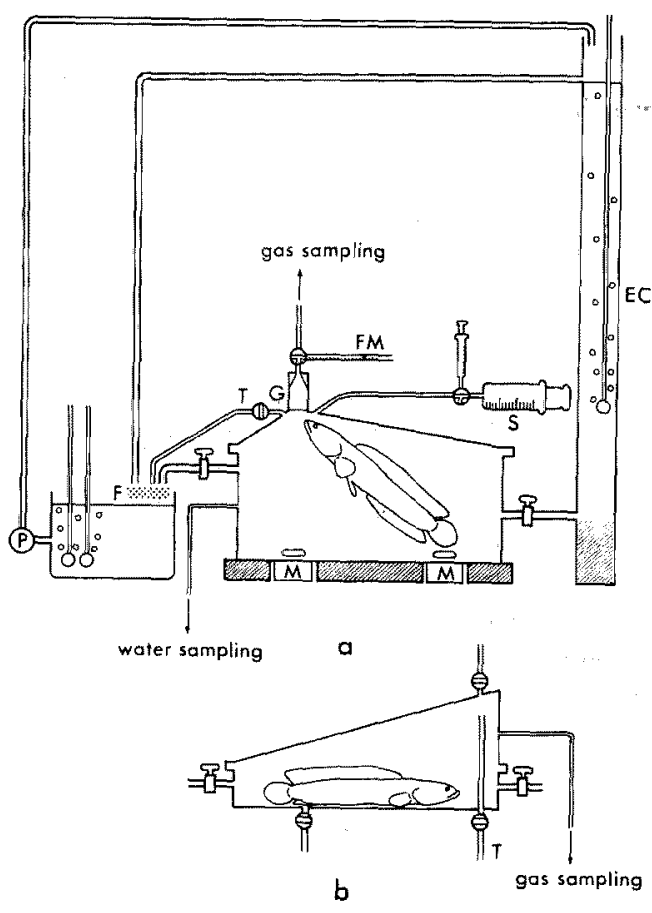

Fig. 1. Diagram of experimental arrangement used for the measurement of gas exchange of Channa during bimodal breathing (a) and during exposure to air (b). EC; equilibration column, F; filter, FM; tubing containing fluid meniscus to maintain the pressure in the system at the atmospheric level, $G$; gas space, $M$; magnetic stirrer, $P$; pump, $S$; syringe to renew the gas in the gas space, $\mathrm{T}$; tubing for water leveling during acclimation period.

and outlet of the chamber were closed and the air flow into the gas space was stopped. Before the fish took first air breath, the gas volume in the gas space was adjusted to $200 \mathrm{ml}$. Air breathing of the snakehead is quite a rapid action. Expiration precedes inspiration, and each requires only about $0.2 \mathrm{~s}$ (IsHimatsu and ITAZAWA, in preparation). Immediately after an air breathing was observed, the total volume of the gas was displaced, by means of depressing the plunger of a large syringe (S), into a glass vessel filled with saturated $\mathrm{LiCl}$ solution from which gas samples were taken. Gas volume in the gas space after an air breath was determined by means of graduations on the large and additional small syringes. Then, about $200 \mathrm{~m} l$ of room air was newly introduced into the gas space ready for next air breath. The same procedure was repeated at each air breath. During an experiment, the pressure in the system was maintained at the atmospheric level by connecting the gas space to the glass tube which had a movable fluid meniscus (FM), $\mathrm{O}_{2}$ and $\mathrm{CO}_{2}$ concentrations of gas samples were determined with a SCHOLANDER micro gas analyzer. Water samples were taken at the beginning and the end of an experiment and $P_{W, 0_{2}}$ of them were measured with a gas analyzing system (Instrumentation Laboratory Inc., Model 113-01) or another one (Beckman, Model 160).

$\mathrm{O}_{2}$ uptake $(\mathrm{mmol} / \mathrm{kg} / \mathrm{h})$ from air $\left(\dot{\mathrm{M}}_{\mathrm{O}_{2} \text { al }}\right)$, that from water $\left(\dot{\mathrm{M}}_{\mathrm{O}_{2} \text { water }}\right)$ and $\mathrm{CO}_{2}$ release (mmol $/ \mathrm{kg} /$ h) to air $\left(\dot{\mathrm{M}}_{\mathrm{CO}_{2} \text { air }}\right)$ were calculated with the following equations;

$$
\begin{aligned}
& \dot{\mathrm{M}}_{\mathrm{O}_{2} \mathrm{alr}}=\frac{\Sigma\left(20.86 \mathrm{~V}_{1}-\mathrm{F}_{\mathrm{O}_{2}} \cdot \mathrm{V}_{2}\right) \cdot f}{22.41 \cdot t \cdot \mathrm{W}} \times 10^{-2} \\
& \dot{\mathrm{M}}_{\mathrm{CO}_{2 \mathrm{al}}}=\frac{\Sigma\left(\mathrm{F}_{\mathrm{CO}_{2}} \cdot \mathrm{V}_{2}-0.08 \cdot \mathrm{V}_{2}\right) \cdot f}{22.26 \cdot t \cdot \mathrm{W}} \times 10^{-2} \\
& \dot{\mathrm{M}}_{\mathrm{O}_{2} \text { water }}=\frac{\beta_{\mathrm{W}, \mathrm{o}_{2}} \cdot \Delta \mathrm{P}_{\mathrm{w}, \mathrm{O}_{2}} \cdot \mathrm{V}}{t \cdot \mathrm{W}}
\end{aligned}
$$

where $\mathrm{V}_{1}$ : gas volume in the gas space before an air breath $(c a .200 \mathrm{ml}) ; \mathrm{V}_{2}$ : gas volume in the gas space after an air breath $(\mathrm{m} l), \mathrm{V}_{2}=\mathrm{V}_{1}+\mathrm{V}_{\mathrm{E}}-\mathrm{V}_{\mathrm{I}}$, where $V_{I I}$ and $V_{I}$ are volumes of expired gas and inspired gas, respectively; $\mathrm{F}_{\mathrm{O}_{2}}$ : fractional concentration of $\mathrm{O}_{2}$ in the gas after an air breath ( $\mathrm{vol} \%$ ); $\mathrm{F}_{\mathrm{CO}_{2}}$ : fractional concentration of $\mathrm{CO}_{2}$ in the gas after an air breath (vol\%); $t$ : time (h); W: body weight $(\mathrm{kg}) ; f$ : correction factor from VaTPs (gas volume at ambient temperature and pressure, saturated with water vapor) to VSTPD (gas volume at standard temperature and pressure, dry); $\beta_{\pi, 0_{2}}$ : capacitance coefficient of $\mathrm{O}_{2}$ in water $\left(1.66 \times 10^{-6}\right.$ $\mathrm{mmol} / \mathrm{m} / / \mathrm{mmHg}$ at $25^{\circ} \mathrm{C}$, Dejours $\left.{ }^{8}\right) ;\left\langle\mathbf{P}_{w, 0_{2}}\right.$ : difference between the initial $P_{w}, o_{2}$ and the final $\mathrm{P}_{\mathrm{w}, \mathrm{O}_{2}}(\mathrm{mmHg}) ; \mathrm{V}$ : water volume $(\mathrm{ml})$. Repeated analyses showed that room air contained 20.86 $\pm 0.04 \mathrm{vol} \%$ of $\mathrm{O}_{2}$ and $0.08 \pm 0.03 \mathrm{vol} \%$ of $\mathrm{CO}_{2}$. One mole of $\mathrm{O}_{2}$ and one mole of $\mathrm{CO}_{2}$ occupy 22.41 and $22.26 l$ (STPD), respectively $\left(\mathrm{SAITO}^{9)}\right)$.

Thus $\dot{\mathrm{M}}_{\mathrm{O}_{2} \text { a!r }}, \dot{\mathrm{M}}_{\mathrm{CO}_{2} \text { alr }}$ and $\dot{\mathrm{M}}_{\mathrm{O}_{2} \text { water }}$ were actually determined but $\dot{\mathrm{M}}_{\mathrm{CO}_{2} \text { water }}$ was estimated from these values with the following equation, because $P_{w}, \mathrm{co}_{2}$ was too low to be reliably measured with our analyzing systems.

$$
\dot{\mathrm{M}}_{\mathrm{CO}_{2} \text { water }}=\mathrm{R}_{\mathrm{tota1}}\left(\dot{\mathrm{M}}_{\mathrm{O}_{2 \text { air }}}+\dot{\mathrm{M}}_{\mathrm{O}_{2} \text { water }}\right)-\dot{\mathrm{M}}_{\mathrm{CO}_{2} \text { alr }}
$$

Total gas exchange ratio $\left(\mathbf{R}_{\text {total }}=\dot{\mathrm{M}}_{\mathrm{co}_{2} \text { total }}\right.$ $\left.\dot{\mathrm{M}}_{\mathrm{O}_{2} \text { tota1 }}\right)$, i.e. respiratory quotient, was assumed to be 0.9 , which is the mean value for 21 species 
of bimodal breathers calculated by RAHN and HOWELL ${ }^{10)}$.

Preliminary experiments without a fish showed that slight diffusion of $\mathrm{O}_{2}$ from air into water occurred in hypoxia experiments. The results were, therefore, corrected for this error.

A smaller plexiglass box (14l) was used to measure gas exchange of air-exposed fish (Fig. 1b). During the acclimation period of $24 \mathrm{~h}$, air-saturated water was circulated through the chamber to allow the fish to breathe bimodally. At the beginning of an experiment, water in the chamber was drained. Thin film of water at the bottom of the chamber prevented the fish from drying during the experiment. Duplicate samples of $1 \mathrm{~m} l$ gas were taken at $1 \mathrm{~h}$ intervals over a period of 3-5 h, and equal volumes of room air were allowed to enter the chamber. The error by this procedure was negligible, and no correction was made for it. Gas samples were analyzed for $\mathrm{O}_{2}$ and $\mathrm{CO}_{2}$ concentrations as described above. Experiments were terminated when $\mathrm{O}_{2}$ concentration fell below 20 vol\%. In this experiment, breathing behavior was observed before, during and after air-exposure using a mirror laid under the chamber. Additionally, branchial breathing rate was counted in two fish breathing bimodally in normoxic and hypoxic water in this chamber.

All values were expressed in mean \pm S.D. For specimens tested twice or three times, mean values of the two or three determinations were used as a single result in calculations for Tables 1-3. Statistical comparisons were made with MANNWHITNEY U test.

\section{Results}

The snakehead surfaced at very irregular intervals both in normoxic and hypoxic water. In normoxic water $90 \%$ of air breathing intervals ranged from $2.5 \mathrm{~min}$ to $17.5 \mathrm{~min}$, but in hypoxic water air breathing intervals became less variable, that is, $90 \%$ of them distributed below $12.5 \mathrm{~min}$ (Fig. 2). Statistical comparison showed that air breathing intervals in hypoxic water were significantly shorter than those in normoxic water $(\mathrm{p}<$ 0.01). Table 1 shows gas exchange of the snakehead during bimodal breathing and during airexposure. Total $\dot{\mathrm{M}}_{\mathrm{O}_{2}}$ was kept constant between normoxia and hypoxia experiments. $\dot{\mathrm{M}}_{\mathrm{o}_{2}}$ by air breathing was significantly higher in hypoxic water than in normoxic water $(\mathrm{p}<0.05)$, while the reverse was true for $\dot{\mathrm{M}}_{\mathrm{O}_{2}}$ by water breathing $(\mathrm{p}<0.01)$. $\dot{\mathrm{M}}_{\mathrm{CO}_{2}}$ by air breathing was not significantly different between these conditions. Estimated values of total $\dot{\mathrm{M}}_{\mathrm{CO}_{2}}$ and $\dot{\mathrm{M}}_{\mathrm{CO}_{2}}$ by water breathing were also not significantly different. Based on these values, partition of gas exchange between air and water breathings was calculated (Table 2). In normoxic water, about $60 \%$ of total $\dot{\mathrm{M}}_{\mathrm{O}_{2}}$ resulted from air

Table 2. Partition of gas exchange in Channa

\begin{tabular}{llcc}
\hline \hline \multicolumn{2}{c}{ Condition } & $\begin{array}{c}\text { Normoxic water } \\
\left(\mathrm{P}_{\mathrm{w}, \mathrm{o}_{2}} \geqq 130 \mathrm{mmHg}\right)\end{array}$ & $\begin{array}{c}\text { Hypoxic water } \\
\left(\mathrm{P}_{\mathrm{w}, \mathrm{o}_{2}} \leqq 40 \mathrm{mmHg}\right)\end{array}$ \\
\hline \multirow{2}{*}{$\dot{\mathrm{M}}_{\mathrm{O}_{2}}$} & AIR & $62 \pm 10$ & $83 \pm 6^{* 2}$ \\
& WATER & $38 \pm 10$ & $17 \pm 6^{* 2}$ \\
\cline { 2 - 4 }$\% \dot{\mathrm{M}}_{\mathrm{CO}_{2}}$ & AIR & $13 \pm 6^{* 1}$ & $16 \pm 7^{* 1}$ \\
& WATER & $87 \pm 6^{* 1}$ & $84 \pm 7^{* 1}$ \\
\hline
\end{tabular}

Number of fish used was 10 for both conditions. Symbols are the same as in Table 1 .

Table 1. Oxygen uptake and carbon dioxide release of Channa during bimodal breathing and in air

\begin{tabular}{|c|c|c|c|c|}
\hline & Condition & $\begin{array}{c}\text { Normoxic water } \\
\left(\mathrm{P}_{\mathrm{w}, \mathrm{O}_{2}} \geqq 130 \mathrm{mmHg}\right)\end{array}$ & $\begin{array}{c}\text { Hypoxic water } \\
\left(\mathrm{P}_{\mathrm{w}, \mathrm{O}_{2}} \leqq 40 \mathrm{mmHg}\right)\end{array}$ & Air-exposed \\
\hline \multirow{3}{*}{$\dot{\mathbf{M}}_{\mathrm{O}_{2}}$} & AIR & $1.26 \pm 0.29$ & $1.80 \pm 0.53^{* 3}$ & \\
\hline & WATER & $0.78 \pm 0.20$ & $0.35 \pm 0.12 * 2$ & \\
\hline & TOTAL & $2.04 \pm 0.29$ & $2.15 \pm 0.56$ & $2.68 \pm 0.68$ \\
\hline \multirow{3}{*}{$\dot{\mathrm{M}}_{\mathrm{CO}_{2}}$} & AIR & $0.24 \pm 0.12$ & $0.33 \pm 0.18$ & \\
\hline & WATER & $1.60 \pm 0.22^{* 1}$ & $1.60 \pm 0.40^{* 1}$ & \\
\hline & TOTAL & $1.84 \pm 0.26^{* 1}$ & $1.93 \pm 0.51^{* 1}$ & $2.02 \pm 0.64$ \\
\hline \multirow{3}{*}{$\mathbf{R}$} & AIR & $0.18 \pm 0.07$ & $0.17 \pm 0.07$ & \\
\hline & WATER & $2.12 \pm 0.35^{* 1}$ & $4.76 \pm 1.03 * 1, * 2$ & \\
\hline & TOTAL & 0.9 & 0.9 & $0.75 \pm 0.07$ \\
\hline
\end{tabular}

$\dot{\mathrm{MO}} \mathrm{O}_{2}$ and $\dot{\mathrm{M}} \mathrm{CO}_{2}$ are expressed in $\mathrm{mmol} / \mathrm{kg} / \mathrm{h}$. Number of fish used was 10 for in normoxic and hypoxic water and 6 for in air. *1 estimated value based on the assumption of total $R$ to be 0.9 .(see Material and Methods). *2, *3 significantly different from values in normoxic water $(* 2 \mathrm{p}<0.01, * a 0.01<\mathrm{p}<0.05)$. 


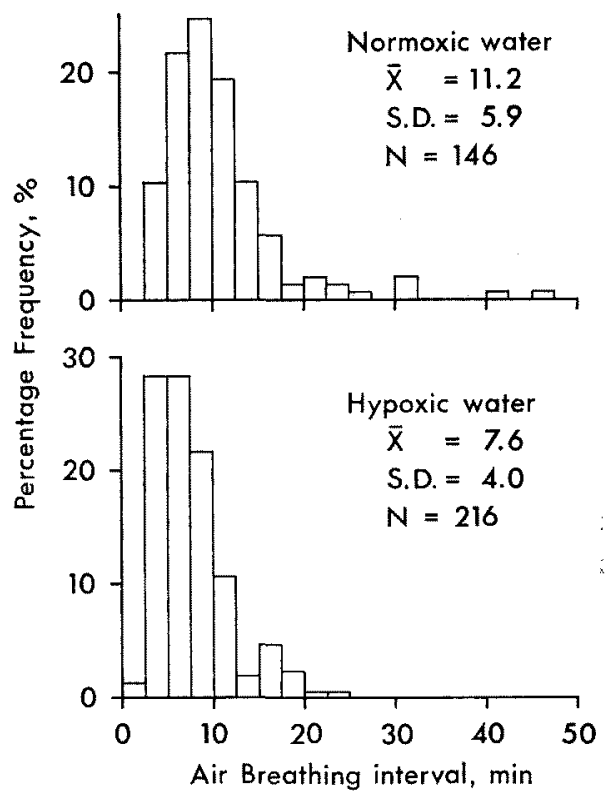

Fig. 2. Distribution of air breathing interval when Channa breathed bimodally in normoxic $\left(\mathrm{P}_{\mathrm{W}, \mathrm{O}_{2}}\right.$ $\geqq 130 \mathrm{mmHg}$, above) and hypoxic $\left(\mathrm{P}_{\mathrm{W}, \mathrm{O}_{2}} \leqq\right.$ $40 \mathrm{mmHg}$, below) water at $25^{\circ} \mathrm{C}$.

Table 3. Oxygen uptake and carbon dioxide release of Channa in each air breath ( $\mathrm{mmol} / \mathrm{kg} /$ breath)

\begin{tabular}{ccc}
\hline Condition & $\begin{array}{c}\text { Normoxic water } \\
\left(\mathrm{P}_{\mathrm{w}, \mathrm{O}_{2}} \geqq 130 \mathrm{mmHg}\right)\end{array}$ & $\begin{array}{c}\text { Hypoxic water } \\
\left(\mathrm{P}_{\mathrm{W}, \mathrm{o}_{2}} \leqq 40 \mathrm{mmHg}\right)\end{array}$ \\
\hline $\mathrm{M}_{\mathrm{O}_{2}}$ & $0.23 \pm 0.03$ & $0.24 \pm 0.05$ \\
$\mathrm{M}_{\mathrm{CO}_{2}}$ & $0.04 \pm 0.01$ & $0.04 \pm 0.01$ \\
\hline \multicolumn{3}{l}{ Number of fish used was 10 for both conditions. }
\end{tabular}

breathing, while only about $15 \%$ of total $\dot{\mathrm{M}}_{\mathrm{CO}_{2}}$ was attributable to this route. In hypoxic water, $\dot{\mathrm{M}}_{\mathrm{O}_{2}}$ by air breathing now amounted to about $85 \%$ of the total, while contribution of air breathing to $\mathrm{CO}_{2}$ release did not significantly increased. This imbalance of gas exchange resulted in low $R$ values for air breathing and high ones for water breathing (Table 1). When $\mathrm{M}_{\mathrm{O}_{2}}$ and $\mathrm{M}_{\mathrm{CO}_{2}}$ by air breathing are recalculated on the basis of each air breath $(\mathrm{mmol} / \mathrm{kg} /$ breath), it becomes clear that the same amount of $\mathrm{O}_{2}$ was taken up and the same amount of $\mathrm{CO}_{2}$ was released in both conditions, on the average, during a breath hold (Table 3). Movement of branchial ventilation was so shallow that it often became imperceptible by visual observation. Branchial breathing rate mostly did not exceed $10 / \mathrm{min}$ and hypoxic water caused no apparent change in it as far as observed.
When exposed to air, fish became inactive at first. The duration of this inactive period varied from $30 \mathrm{~min}$ to over $2 \mathrm{~h}$ depending on fish. When fish became active, they gulped air at intervals of less than 1 min. $\quad \dot{\mathrm{M}}_{\mathrm{O}_{2}}$ in air appeared to be slightly higher than total $\dot{\mathrm{M}}_{\mathrm{O}_{2}}$ during bimodal breathing, but this was not statistically significant $(\mathrm{p}>0.05$ ) (Table 1). $\quad \dot{\mathrm{M}}_{\mathrm{CO}_{2}}$ was also maintained in air at the same level as total $\dot{\mathrm{M}}_{\mathrm{Co}_{2}}$ during bimodal breathing. Total $\mathbf{R}$ was 0.75 during air-exposure.

\section{Discussion}

The snakehead is a typical bimodal breather. At $25^{\circ} \mathrm{C}$, the fish can survive indefinitely in hypoxic water with access to air but succumbs, even in well aerated water, when prevented from surfacing. In other words, the fish is an obligate air breather at this temperature.

Recently BURGGREN and CAMERON ${ }^{11)}$ measured $\dot{\mathrm{M}}_{\mathrm{O}_{2}}$ and $\dot{\mathrm{M}}_{\mathrm{CO}_{2}}$ of a purely water-breathing channel catfish Ictalurus punctatus in normoxic and hypoxic water. They found that $\dot{\mathrm{M}}_{\mathrm{O}_{2}}$ was kept constant but $\dot{\mathrm{M}}_{\mathrm{CO}_{2}}$ doubled in hypoxic water $\left(\mathrm{P}_{\pi, \mathrm{O}_{2}}=65\right.$ $\mathrm{mmHg}$ ). As a result, the gas exchange ratio increased from 0.8 in normoxic water to 2.0 in hypoxic water. They concluded that this increased $\dot{\mathrm{M}}_{\mathrm{CO}_{2}}$ in hypoxic environment was mainly due to lactate acidification of the tissue $\mathrm{HCO}_{3}{ }^{-}$, rather than from metabolic production of molecular $\mathrm{CO}_{2}$. In air-breathing fish which can utilize atmospheric air, however, the fish is likely to rely on air breathing to a larger extent in hypoxic water than in normoxic water, and anaerobic metabolism seems not to develop even in the former condition. BURGGREN's experiment ${ }^{12)}$ in an air-breathing blue gourami Trichogaster trichopterus seems to support this idea. Actually, the gas exchange ratio was maintained at the same level as in normoxic water when water $\mathbf{P}_{\mathrm{O}_{2}}$ fell down to $56 \mathrm{mmHg}$. Based on the above considerations, the assumption on $\mathrm{R}$ adopted in the present study is thought to be valid.

The present study clearly demonstrates that the air-breathing organ of the snakehead functions mainly for $\mathrm{O}_{2}$ uptake but little for $\mathrm{CO}_{2}$ release (Tables 1 and 2). The gills of the snakehead are relatively well developed on the 1st and 2 nd gill arches while the gills on the 3rd and especially those on the 4th one show degenerated appearances $^{5}$. So most of $\mathrm{CO}_{2}$ release may take place on the 1st and 2nd gill arches although the extremely shallow ventilatory movement of the gills 
may suggest that some part of $\mathrm{CO}_{2}$ release is carried out cutaneously. Efferent branchial arteries of the 1st and 2nd gill arches send the blood to the air-breathing organ. This serial arrangement may facilitate aerial $\mathrm{O}_{2}$ uptake, because $\mathrm{P}_{\mathrm{CO}_{2}}$ of the blood must fall before the blood enters the airbreathing organ by efficient release of $\mathrm{CO}_{2}$ at the gills. Our unpublished data show that the oxygen affinity of the blood of the snakehead is modulated by $\mathrm{P}_{\mathrm{CO}_{2}}$ (BoHR effect). The $3 \mathrm{rd}$ and 4 th gill arches send the blood to the systemic circulation ${ }^{b)}$. Degenerated structure of these two arches may reduce oxygen loss from the blood into water when the fish is in severely hypoxic water as in their natural habitat. Air-breathing organs of all air-breathing fishes ever studied have very low gas exchange ratio during bimodal breathing as summarized by RAHN and HoweLL ${ }^{10)}$. This means that the airbreathing organs of these animals have enough ability to obtain $\mathrm{O}_{2}$ from air but not so regarding $\mathrm{CO}_{2}$ release to air.

The large variability of air breathing interval (Fig. 2) is puzzling. Johansen and Lenfant ${ }^{13 \text { ) }}$ observed more marked variability of the interval in the African lungfish Protopterus. They surmised, based on determination of blood gas tensions, that the fish tolerated internal variations in gas tensions rather than regulated these parameters. We now succeeded in blood gas analysis only within $5 \mathrm{~min}$ after air breathing (IsHTMATSU and ITAZAWA, unpublished). Gas analysis of blood for a long duration after air breathing is necessary in order to clarify what occurs internally during longer breath hold.

The snakehead maintained $\dot{\mathrm{M}}_{\mathrm{O}_{2}}$ at the same level as during bimodal breathing when the fish was exposed to air. Carbon dioxide was also rather effectively released so that the gas exchange ratio was 0.75 . Among other air-breathing fishes, some can maintain or increase $\dot{\mathrm{M}}_{\mathrm{O}_{2}}$ when exposed to air. The Cuchia eel Amphipnous ${ }^{14)}$, the South American swamp eel Synbranchus ${ }^{15)}$, and the blue gourami Trichogaster ${ }^{18)}$ belong to this group. The climbing perch Anabas $^{17)}$, the eel Anguilla $^{18)}$, and Saccobranchus ${ }^{19)}$ show decreased $\dot{\mathrm{M}}_{\mathrm{O}_{2}}$ in air. Most air-breathing fishes appear to lack enough ability to release $\mathrm{CO}_{2}$ when in air. Saccobranchus showed the gas exchange ratio of as low as 0.58 during airexposure $^{19)}$. The Australian lungfish Neoceratodus $^{20)}$ and the jeju Hoplerythrinus ${ }^{21)}$ suffered from hypercapnic acidosis in this condition. Exceptionally the blue gourami showed increased $\dot{\mathrm{M}}_{\mathrm{CO}_{2}}$ during air-exposure ${ }^{16)}$. The unusual ability

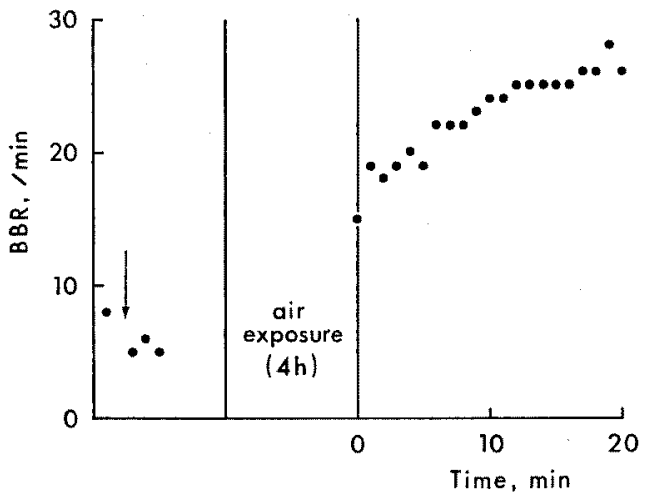

Fig. 3. Change in branchial breathing rate (BBR) before and after air-exposure of $4 \mathrm{~h}$. A vertical arrow indicates air breathing. Before and after air-exposure, the fish breathed bimodally in normoxic water.

of this fish is attributed to the presence of carbonic anhydrase in the epithelium of the "labyrinthine" organ. This is to be expected, because the organ is an outgrowth of the 1st gill $\operatorname{arch}^{22}$ and the gills are known to be rich in the enzyme ${ }^{18,23)}$.

MUNSHI ${ }^{4)}$ regarded the suprabranchial chamber of the snakehead as a modified gill but later this was proved not to be true by electron microscopic study ${ }^{24)}$. Accordingly, $\mathrm{CO}_{2}$ release of the snakehead in air is unlikely due to the presence of the enzyme in the air-breathing organ. The other respiratory organ, the gills, is therefore probably responsible for $\mathrm{CO}_{2}$ release in air, just as in water. The widely spaced arrangement of secondary lamellae as well as their low height/length ratio ${ }^{26)}$ suggests that the gills of this fish may be functional in air.

The fact that $\mathrm{R}$ was 0.75 does not exclude the possibility that the level of blood $\mathrm{P}_{\mathrm{Co}_{2}}$ was elevated during air-exposure. Markedly increased rate of gill ventilation after the fish was returned to water (Fig. 3) may have resulted from the accumulation of $\mathrm{CO}_{2}$ during air-exposure.

\section{Acknowledgments}

The authors wish to thank Prof. H. KoBayashr, Shimonoseki University of Fisheries, for his kind providing of the cuvette for Beckman 160.

\section{References}

1) K. Johansen: in "Fish Physiology" (ed. by W. S. Hoar and D. J. Randali), Vol. 4, Acade- 
mic Press, New York, 1970, pp. 361-411.

2) J. S. Datta MunshI: in "Respiration of Amphibious Vertebrates"' (ed. by G. M. HuGHEs), Academic Press, New York, 1976, pp. 73-104.

3) Y. Fukuda: Zool. Mag., Tokyo, 80, 181-190 (1971).

4) J. S. Datta Munshi: J. Linn. Soc. Lond. (Zool.), 44, 616-626 (1962).

5) A. Ishimatsu, Y. ITAZAWA and T. TAKedA: Japan J. Ichthyol., 26, 167-180, (1979).

6) K. UCHIDA and M. Fummoto: Bull. Fish. Exp. Stn. Chosen, 3, 1-91 (1933).

7) M. G. EmLlo and G. Shelton: J. exp. Biol., 60, 567-579 (1974).

8) P. DeJours: Principles of Comparative Respiratory Physiology, North-Holland, Amsterdam, 1975, p. 22.

9) K. SAITo: San Enki Heiko no Kiso, Asakurashoten, Tokyo, 1972, p. 4.

10) H. RAHN and B. J. Howell: in "Respiration of Amphibious Vertebrates" (ed. by G. M. HuGHEs), Academic Press, New York, 1976, pp. 271-285.

11) W. W. Burggren and J. N. Cameron: J. exp. Zool., 213, 405-416 (1980).

12) W. W. Burgaren: J. exp. Biol., 82, 197-213 (1979).

13) K. JohANSEN and C. LeNFANT: $J$. exp. Biol.,
49, 453-468 (1968).

14) J. P. LOMHolt and K. Johansen: J. comp. Physiol., 107, 141-157 (1976).

15) J. E. P. W. Bicudo and K. JohanSEn: Env. Biol. Fish., 4, 55-64 (1979).

16) W. W. Burggren and M. S. Haswell: I. exp. Biol., 82, 215-225 (1979).

17) G. M. Hughes and B. N. Singh: J. exp. Biol, 53, 265-280 (1970).

18) T. Berg and J. B. STEEN: Comp. Biochem. Physiol., 15, 469-484 (1965).

4, 55-64 (1979).

19) G. M. Hughes and B. N. Singh: J. exp. Biol, 55, 667-682 (1971).

20) C. Lenfant, K. Johansen and G. C. Grigg: Resp. Physiol., 2, 1-21 (1966/67).

21) D. J. RANDall, A. P. FARRell and M.S. HASWELL: Can. J. Zool., 56, 970-973 (1978).

22) B. K. DAS: Phil. Trans. Roy. Soc, London, Ser. $B, 216,183-219$ (1928).

23) M.S. Haswell and D. J. Randall: $J$. exp. Biol., 72, 17-24 (1978).

24) G. M. Hughes and J. S. Datta Munsh: - J. Zool., Lond., 170, 245-270 (1973).

25) O. TAmura and T. Moriyama: Bull. Fac. Fish. Nagasaki Univ., 41, 1-8 (1976). 